\title{
STRATEGI PENINGKATAN LIKUIDITAS DI BANK SYARIAH MANDIRI KCP PADANG PANJANG MELALUI PENAMBAHAN CUSTOMER BASE
}

\author{
Li Iswandi \\ Mahasiswa Ekonomi Syariah, Program Pascasarjana IAIN Batusangkar \\ e-mail: li.iswadi@gmail.com
}

\begin{abstract}
The strategy to increase liquidity at Bank Syariah Mandiri (BSM) KCP Padang Panjang is by increasing the customer base. The purpose of this study was to see the extent of the strategy to increase liquidity at BSM KCP Padang Panjang through the addition of a customer base. This research was conducted at Bank Syariah Mandiri KCP Padang Panjang using a qualitative descriptive method. Qualitative descriptive, namely processing data by collecting more data and describing it thoroughly and in accordance with the problem being studied, so that a result of data processing will be obtained which is called research results. In this study, the type of data used is primary data, namely field data obtained directly from the people or actors who are the subjects of this study, such as through the results of interviews that have been conducted. The source of information from this study is the Branch Manager of BSM KCP Padang Panjang. Meanwhile, the secondary data sources are documents related to the problem of this research in BSM KCP Padang Panjang. The results show that liquidity problems are experienced every day by banks, both conventional and Islamic, where one of them is the unbalanced position between TPF and financing that is given every day, that is, the higher TPF that enters than the channeled financing, or vice versa.
\end{abstract}

Kata Kunci: strategi ,likuiditas, costumer base

\section{LATAR BELAKANG}

Perbankan syariah sebagai lembaga intermediary berfungsi sebagai perantara antara pemilik dana dan pemakai dana. Dalam menjalankan fungsinya tersebut, bank bertindak sebagai pemilik dana sekaligus bertindak sebagai pemakai dana. Maka urgansi manajemen likuiditas merupakan salah satu hal yang penting dalam memelihara kepercayaan masyarakat terhadap bank tersebut. Karena likuiditas 
menyangkut posisi uang kas bank dan kemampuannya untuk memenuhi kewajiban (membayar hutang) oleh nasabah yang ditagih dengan tiba-tiba atau pihak terkait apabila jatuh tempo. (Departemen Pendidikan Nasional, 2002)

Salah satu penyebab kebangkrutan suatu bank adalah karena ketidakmampuannya dalam memenuhi kebutuhan likuiditasnya. Likuiditas pada umumnya didefinisikan sebagai kepemilikian sumber dana yang memadai untuk memenuhi seluruh kebutuhan kewajiban yang akan jatuh tempo. Atau dengan kata lain kemampuan perusahaan untuk memenuhi kewajiban pada saat ditagih baik yang dapat diduga ataupun yang tidak terduga. Dari sudut aktiva, likuiditas adalah kemampuan untuk mengubah seluruh asset menjadi bentuk tunai (cash). Sedangkan dari sudut pasiva, likuiditas adalah kemampuan memenuhi kebutuhan dana melalui peningkatan portofolio liabilitas

Dalam usaha mempertahankan likuiditas pada posisi yang ideal, bank dituntut untuk selalu menjaga penarikan dana dari sumber dana yang dititipkannya dalam bentuk giro, tabungan, dan deposito. Namun di sisi lain bank berkewajiban menjaga penarikan permintaan dana seperti pembiayaan yang diberikan. Keadaan seperti menunjukkan adanya hubungan yang saling mempengaruhi antara likuiditas dan profitabilitas yang umumnya terjadi tarik kepentingan (trade-off), yaitu jika likuiditas tinggi, maka profitabilitas bank akan rendah. Barlaku sebaliknya, jika likuiditas rendah maka profitabilitas bank akan tinggi.

Kondisi di atas membutuhkan pengendalian instrumen atau alatalat likuid yang mudah ditunaikan guna memenuhi semua kewajiban bank yang segera di bayar dengan menjaga efisiensi bank yang akan berdampak pada meningkatnya profitabilitas bank. Jika tidak, maka akan terjadi risiko likuiditas yang akhirnya akan mengganggu kegiatan operasional bank. (Muhammad, 2004)

Oleh karenanya dirasa penting bagi Bank Syariah Mandiri KCP Padang Panjang untuk terus memelihara dan meningkatkan tingkat likuiditasnya, salah satunya dengan menerapkan strategi untuk meningkatkan penambahan costumer base dalam penggunaan produk-produk BSM yang otomatis 
juga akan berefek pada peningkatan likuiditas BSM KCP Padang Panjang dari segi penambahan dana yang disimpan di BSM KCP Padang Panjang.

\section{METODOLOGI PENELITIAN}

Penelitian ini dilakukan pada BSM KCP Padang Panjang. Penelitian ini dilakukan dengan menggunakan metode deskriptif kualitatif. Deskriptif Kualitatif yaitu mengolah data dengan lebih banyak mengumpulkan data dan menguraikannya secara menyeluruh dan sesuai dengan permasalahan yang sedang diteliti, sehingga akan diperoleh suatu hasil dari pengolahan data yang disebut hasil penelitian.

Pada penelitian ini jenis data yang digunakan adalah data primer yaitu data data lapangan yang diperoleh langsung dari orang-orang atau pelaku yang menjadi subjek dalam penelitian ini seperti melalui hasil wawancara yang telah dilakukan.Sumber informasi dari penelitian ini adalah Branch Manager BSM KCP Padang Panjang. Sedangkan yang menjadi sumber data sekunder adalah dokumen yang berkaitan dengan permasalah penelitian ini yang ada di BSM KCP Padang Panjang

\section{LANDASAN TEORI}

\section{Likuiditas}

Likuiditas menurut Endang (2011) adalah kemampuan untuk memenuhi kebutuhan dana (cash flow) dengan segera dan dengan biaya yang sesuai. Fungsi dari likuditas secara umum adalah untuk:

a. Menjalankan transaksi bisnisnya sehari-hari.

b. Mengatasi kebutuhan dana yang mendesak.

c. Memuaskan permintaan nasabah akan pinjaman dan memberikan fleksibiltas dalam meraih kesempatan investasi menarik yang menguntungkan.

Menurut Zainul Arifin (2003) Likuiditas bank adalah kemampuan bank untuk memenuhi kewajibannya, terutama kewajiban dana jangka pendek. Dari sudut aktiva, likuiditas adalah kemampuan untuk mengubah seluruh asset menjadi bentuk tunai (cash). Sedangkan dari sudut pasiva, likuiditas adalah kemampuan memenuhi kebutuhan dana melalui peningkatan portofolio liabilitas

Secara umum, pengertian likuditas adalah kemampuan untuk 
memenuhi kebutuhan dana (cash flow) dengan segera dan dengan biaya yang sesuai, dimana fungsi dari likuditas secara umum untuk (Riyanto, 2001): pertama, menjalankan transaksi bisnisnya sehari-hari. Kedua, mengatasi kebutuhan dana yang mendesak. Ketiga, memuaskan permintaan nasabah akan pinjaman dan memberikan fleksibiltas dalam meraih kesempatan investasi menarik yang menguntungkan.

\section{Manajemen Likuiditas Bank}

Manajemen likuiditas bank dapat diartikan sebagai suatu proses pengendalian dari alat-alat likuid yang mudah ditunaikan guna memenuhi semua kewajiban bank yang segera harus dibayar.

Pengendalian likuiditas bank setiap hari berupa penjagaan agar semua alat alat likuid yang dapat dikuasai oleh bank (uang tunai kas, saldo bank pada bank sentral) dapat dipergunakan untuk memenuhi munculnya tagihan dari nasabah atau masyarakat yang datang setiap saat atau sewaktu waktu (Sinungan, 1993).

Dengan demikian dapat disimpulkan bahwa manajemen likuiditas bank adalah kemampuan dari suatu bank untuk membiayai peningkatan aset yang sesuai dengan kewajibannya pada saat jatuh tempo. Likuiditas sangat penting bagi keberlangsungan operasi bank karena itu di perlu manajemen dan pengelolaan yang efektif untuk menghindari terjadinya permasalahan yang serius dikemudian hari. Kekurangan likuiditas pada suatu bank dapat mengakibatkan pengaruh yang lebih luas dan berdampak negatif pada sistem perbankan. Pengelolaan likuiditas adalah kegiatan yang rutin dalam operasi bank dimana dana yang dikelola sebagian besar adalah dana pihak ketiga yang sifatnya sangat berfluktuasi. Bank harus memperhitungkan dengan cermat kebutuhan likuiditas untuk suatu jangka waktu tertentu karena kebutuhan likuiditas sangat dipengaruhi oleh perilaku nasabah dan jenis sumber dana yang dikelola bank.

Kesulitan likuiditas seringkali menjadi tanda-tanda awal bahwa suatu bank akan mengalami kesulitan finansial yang lebih serius. Kesulitan ini biasanya diawali dengan turunnya simpanan (depposite) masyarakat yang menyebabkan kekurangan alat likuid sehingga terpaksa harus melakukan pinjaman antar bank dan menjual aktiva cadangannya. Kesulitan itu akan bertambah parah jika bank-bank 
lain mulai menolak memberikan bantuan atau pinjaman kepada bankbank yang bermasalah.

Dalam keadaan sulit bank cenderung akan berusaha memperoleh pinjaman dana dengan biaya berapapun untuk menjaga citranya. Kemampuan ini berarti bank mengorbankan profit untuk kepentingan likuiditas. Kemampuan bank dalam mengelola likuiditasnya secara baik dapat menjamin terpenuhinya kewajiban secara tertib sehingga bank itu akan terhindar dari resiko biaya pinjaman yang tinggi.

Adapun tujuan manajemen likuiditas adalah untuk (Leon dan Ericson,2007):

a. Menjaga posisi likuiditas bank agar selalu berada pada posisi yang ditentukan oleh otoritas moneter yaitu Bank Indonesia.

b. Mengelola alat-alat likuid agar selalu memenuhi semua kebutuhan arus kas termasuk kebutuhan yang tidak diperkirakan, misalnya penarikan yang tiba-tiba terhadap sejumlah giro atau deposito berjangka yang belum jatuh tempo.

c. Meminimalkan idle fund (dana yang menganggur).

d. Menjaga posisi likuiditas dan proyeksi arus kas agar selalu dalam posisi aman terutama dalam tingkat bunga berfluktuatif.

Selain tujuan di atas, menurut Sinkey ada lima fungsi utama manajemen likuiditas bank, yaitu (Latumaerisa: 1999):

a Menunjukan dirinya sebagai tempat yang aman untuk menyimpan uang. Mampu memberikan rasa aman kepada para nasabah deposan, penabung, maupun kreditor lainnya. Fungsi utama likuiditas adalah jaminan bahwa uang yang disimpan/dipinjamkan kepada bank dapat dibayar kembali oleh bank tersebut pada saat jatuh tempo.

b. Memungkinkan bank memenuhi komitmen pinjamannya. Menjamin tersedianya dana bagi setiap pemohon kredit yang telah disetujui. Jika bank menolak untuk menyediakan dana atas permohonan kredit yang telah disetujui, mungkin debitor akan lari ke bank lain. Sebaiknya bank mampu mengantisipasi kebutuhankebutuhan para debitor di masa mendatang.

c. Untuk menghindari penjualan aktiva yang tidak menguntungkan 
Mencegah penjualan asset secara terpaksa. Apabila bank tidak dapat memperpanjang pinjaman yang diterima dari bank lain, salah satu cara untuk mengatasi masalah tersebut adalah dengan terpaksa menjual surat berharga yang umumnya dengan harga rendah. Hal itu jelas akan memperburuk tingkat modal bank tersebut.

d. Untuk menghindarkan diri dari penyalahgunaan kemudahan atau kesan "negative" dari penguasa moneter karena meminjam dana likuiditas dari bank sentral. Menghindari diri dari kewajiban membayar suku bunga yang tinggi atas dana yang diperoleh di pasar uang. Pemilik dana menganggap bahwa

menempatkan/meminjamkan

dana pada bank beresiko tinggi.

Oleh karena itu, pemilik dana akan selektif dan mungkin akan menempatkan dananya dengan suku bunga yang tinggi.

e. Memperkecil penilaian risiko ketidakmampuan membayar kewajiban penarikan dana. Menghindarkan diri dari penggunaan fasilitas discount window secara terpaksa. Semakin sering suatu bank menggunakan fasilitas discount window, semakin tidak bebas manajemen bank tersebut menentukan dan melaksanakan kebijakan usahanya. Hal itu karena bank sentral akan mendikte manajemen bank tersebut untuk memperbaiki tingkat kesehatan banknya.

\section{Manajemen Likuiditas Bank Syariah}

Manajemen Likuiditas bank adalah mengelola bagaimana bank dapat memenuhi baik kewajiban yang sekarang maupun kewajiban yang akan dating bila terjadi penarikan atau pelunasan asset liability yang sesuai perjanjian ataupun yang belum diperjanjikan (tidak terduga). Pengelolaan likuiditas bank juga merupakan bagian dari pengelolaan liabilitas (liability management). Melalui pengelolaan likuiditas yang baik, bank dapat memberikan keyakinan pada para penyimpan dana bahwa mereka dapat mengambil dananya sewaktu- waktu atau pada saat jatuh tempo. Oleh karena itu, bank harus mempertahankan sejumlah alat likuid guna memastikan bahwa bank sewaktu-waktu dapat memenuhi kewajiban jangka pendeknya.

Suatu bank syari'ah dikatakan likuid apabila (Muhammad, 2004): 
a. Dapat memelihara GWM di Bank Indonesia sesuai dengan ketentuan yang berlaku.

b. Dapat memelihara Giro di Bank Koresponden. Giro di Bank Koresponden adalah rekening yang dipelihara di Bank Koresponden yang besarnya ditetapkan berdasarkan Saldo Minimum.

c. Dapat memelihara sejumlah kas secukupnya untuk memenuhi pengambilan uang tunai.

Dalam pengelolaan dana, bank akan mengalami salah satu dari tiga hal di bawah ini :

a. Posisi seimbang (squere) dimana persedian dana sama dengan kebutuhan dana yang tersedia

b. Posisi lebih (long) dimana persediaan dana lebih dari kebutuhan dana yang tersedia.

c. Posisi kurang (short) dimana persediaan dana kurang dari kebutuhan dana.

Dalam kegiatan operasional, bank dapat mengalami kelebihan atau kekurangan likuiditas. Apabila terjadi kelebihan maka hal itu dianggap sebagai keuntungan bank. Sedangkan jika terjadi kekurangan likuiditas, maka bank memerlukan sarana untuk menutupi kekurangan tersebut (Widyaningsih, 2005).

\section{HASIL DAN PEMBAHASAN}

Pengelolaan likuiditas merupakan salah satu masalah yang sangat kompleks, hal ini menyangkut masalah dana yang dihimpun oleh perbankan dari Dana Pihak Ketiga (DPK) yang sebagian besar sifatnya adalah jangka pendek dan datangnya tidak terduga. Permasalahan likuiditas pasti dialami setiap harinya oleh pihak perbankan, baik yang konvensional maupun Islam di mana salah satunya adalah posisi antara DPK dan Pembiayaan yang diberi-kan)yang setiap harinya tidak seimbang, yaitu lebih besar DPK yang masuk dari pada pembiayaan yang disalurkan, atau sebaliknya.

Untuk di BSM KCP Padang Panjang dimana pada semester 1 tahun 2020 posisi pembiayaan lebih besar daripada DPK, maka dilakukan strategi penambahan costumer base baik untuk melakukan menyimpanan dana maupun untuk melakukan pembiayaan yang juga berefek secara langsung maupun tidak langsung akan meningkatkan DPK BSM KCP Padang Panjang. 


\section{KEPUSTAKAAN ACUAN}

Arifin, Zainul, Dasar-Dasar Manajemen

Bank Syariah, Cetakan 4, 2006

Departemen Pendidikan Nasional,

2002. Kamus Besar Bahasa

Indonesia, edisi ketiga, Jakarta:

Balai Pustaka

Latumaerissa, Julius R. 1999. Mengenal

Aspek-Aspek Operasi Bank Umum.

Jakarta: Bumi Aksara

Muhammad, 2004. Manajemen Dana

Bank Syariah, Yogyakarta:

EKONISIA Simorangkir,

Pengantar Lembaga Keuangan Bank

$\mathcal{E}$ Non Bank, Bogor: Ghalia

Indonesia, 2004

Sinungan, Muchdarsyah. 1997.

Manajemen Dana Bank.

Jakarta:Bumi Aksara. Yahia

Abdul-Rahman, Islamic

Instruments For Managing

Liquidity, International

Journal of Islamic Financial Services Vol.

1 No.1. 